\title{
Manipulating Fruit Tree Structure Chemically and Genetically for Improved Performance
}

\author{
J.D. Quinlan and K.R. Tobutt \\ Institute of Horticultural Research, East Malling, Maidstone, Kent ME19 6BJ, United Kingdom
}

Fruit growers and nurserymen have long been familiar with cultivar differences in tree growth habit resulting from variability in such characteristics as internode length, branch angle, the tendency for buds to produce lateral shoots or spurs, and the degree of acrotony or basitony. These differences'. are significant horticulturally when they influence management practices and tree performance.

For example, it is well-known that a strong primary branch framework is most easily formed from lateral shoots (feathers) present on apple trees at time of transplanting from the nursery to the orchard (40). Likewise, the value of these feathers in providing sites for the early production of flowers and crop is well-established, at least in apple (50); this fact is particularly important where trees are planted in high-density systems, the economic viability of which depends largely upon good cropping from an early stage in the life of the orchard, to provide income to repay the large orchard establishment costs as soon as possible. Failure of a cultivar to branch adequately at the nursery stage is an undesirable trait that, although modified by growing conditions, is under genetic control.

At later stages, also, management and productivity of tree fruits may be influenced by cultivar differences in tree structure. Thus, 'Spartan', 'Bigarreau Gaucher' and 'Czar', examples of apple, sweet cherry, and European plum, respectively, present problems because of their upright growth habit, whereas 'Golden Delicious', 'Bigarreau Jaboulay' and 'Victoria' have more spreading forms and are more easily managed.

Pruning and mechanical manipulation of tree structure are methods by which the grower may attempt to mold trees to the desired form. Structural deficiencies may also be modified by chemical treatments or overcome by the breeder producing new forms.

Some developments in chemical and genetic manipulation of fruit tree structure are considered in relation to improvement of tree performance.

\section{CHEMICAL MANIPULATION OF TREE STRUCTURE}

The nursery tree

Reference has already been made to the benefits to the grower from planting well-branched trees when establishing an orchard. The ease with which branches are produced by the nursery tree is to a large extent a cultivar characteristic; even with good nursery management, many cultivars of a wide range of tree fruits branch inadequately. -

The interaction of endogenous growth regulators is thought to control the outgrowth of axillary buds, with auxins and cytokinins playing major roles (46). The influence of the shoot apex and young leaves in limiting axillary bud outgrowth from the nodes below is well-established (7), and differences in levels of endogenous growth regulators present in these tissues may be related to the propensity of cultivars to produce lateral shoots $(1,6)$. Although removal of the shoot tip induces an increase in lateral shoot production by the nursery tree, the resulting tree structure is undesirable in that the branch angles tend to be too acute, giving an upright tree form. Removal of the very young shoot tip leaves may result in an increase in production of lateral shoots forming wide branch angles (7), but the treatment is too delicate and time-consuming to be of use to nursery workers.

Suppression of apical dominance by application of chemical treatments has been widely investigated and the. many chemicals shown to induce branching of nursery fruit trees include maleic hydrazide (6), diphenyl urea (6), and methyl esters of long-chain fatty acids (43); the latter mixture selectively damages the young leaves at the shoot tip, simulating the effect of young leaf removal. Chemicals that interfere with the endogenous hormone system, such as the auxin transport inhibitors triiodobenzoic acid (TIBA) (6) and $n$ propyl-3-t-butylphenoxyacetate (M\&B 25-105) (41, 51, 53), also result in increased branching. Other growth regulators such as the cytokinin benzyladenine, used alone or in combination with giberellins $_{4+7}$ (Promalin), may supplement endogenous hormones and stimulate branching of several species $(19,20)$.

In the United. Kingdom, M\&B 25-105 is now routinely used to treat poorly branching cultivars such as 'Spartan' apple (Fig. 1); this treatment can result in an improved primary branch framework in the orchard tree with increased cropping in the early years (Fig. 2).

\section{The young orchard tree}

Strong apical dominance can also be exhibited by the young orchard tree, resulting in a poor rate of canopy development and delayed bearing. Hand-pruning, when carried out simply to stimulate lateral shoot production, is wasteful of the tree's resources and results in the removal of potential fruiting points. The rapid development of the secondary branch framework is an important factor determining the level of productivity. Several cultivars of many tree fruits, including some of the most widely grown apple spur-types, often show only limited secondary branching. Several workers have investigated the use of chemical branching agents on young orchard trees to reduce the need for hand-pruning and to improve early cropping by stimulating development of the bearing surface.

Forshey (23), Elfving (20), and Miller et al. (37) tested the use of benzyladenine (BA) applied alone and in combination with $\mathrm{GA}_{4+7}$ to improve branch development in young trees of a range of apple cultivars. Many reponded positively, with the spur-types generally showing the greatest development of lateral shoots following treat-
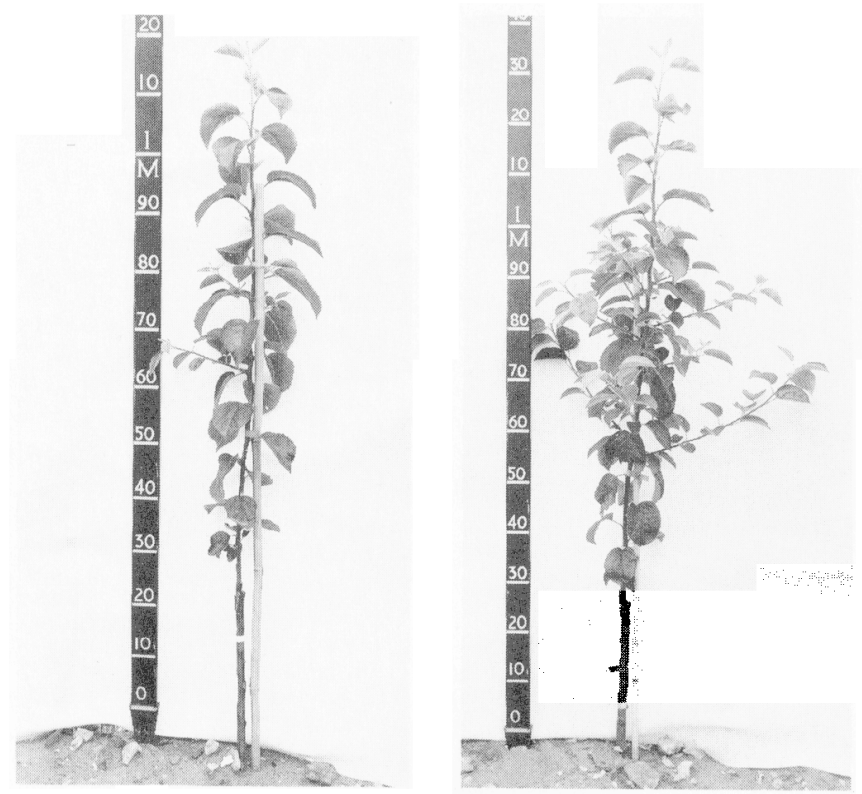

Fig. 1. 'Spartan' apple of MM.106 m the nursery. (Left) Untreated. (Right) Sprayed with the branching agent M\&B 25-105 when tree height was 75 $\mathrm{cm}$. Photographed 2 months after treatment. 

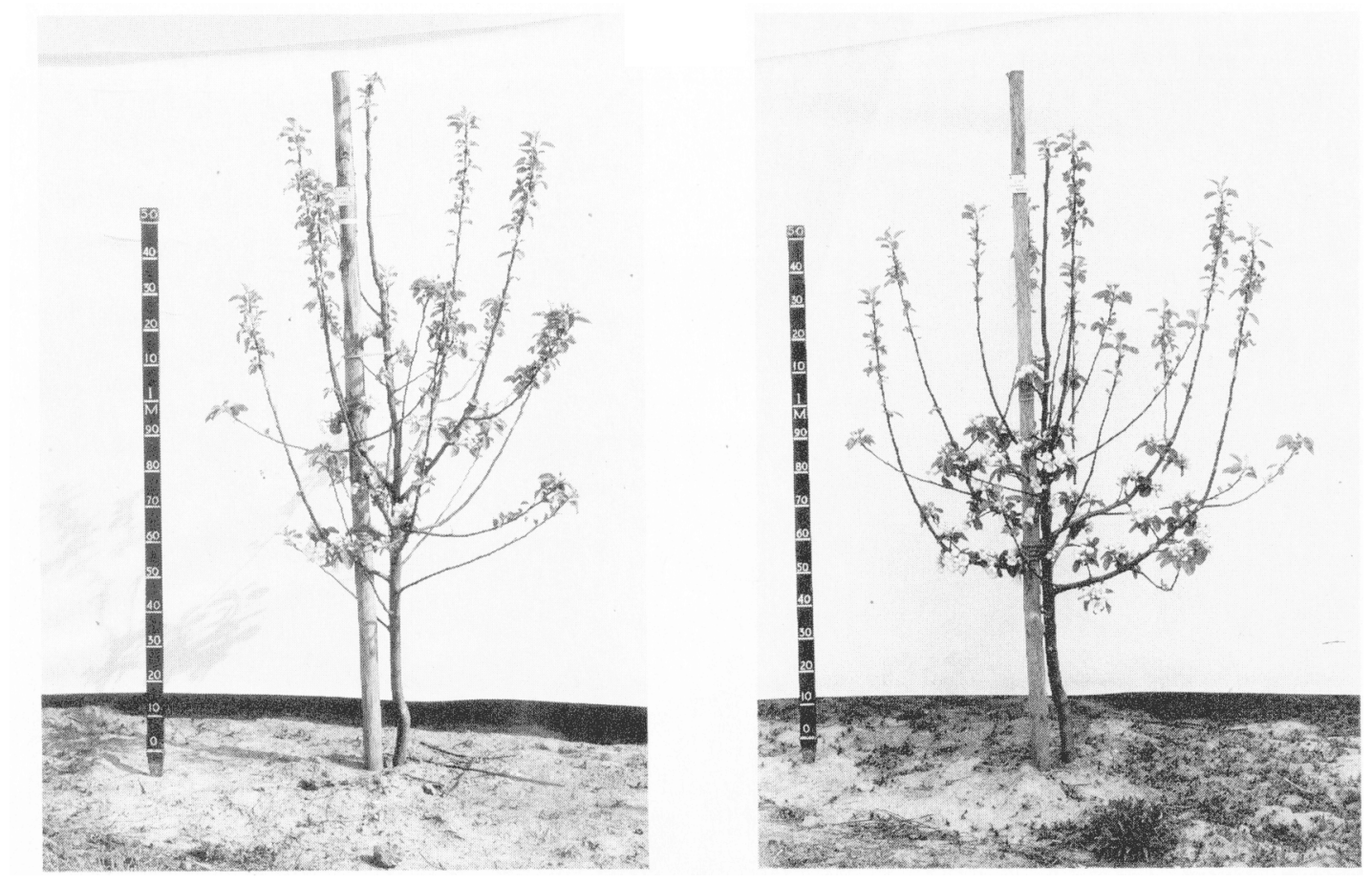

Fig. 2. 'Spartan' apple on MM. 106 at the beginning of the third orchard year. (Left) Untreated. (Right) Sprayed in the nursery with the branching agent M\&B 25-105. The nursery treatment increased yield from 6.6 to $11.1 \mathrm{~kg} /$ tree.

ment. Although these results indicate an improved cropping potential, data were not presented for effects on cropping levels. Quinlan and Preston (44) used the fatty acid ester mixture "Off-Shoot-O" to replace hand-pruning of young trees of the predominantly tipbearing apple cultivar Bramley's Seedling. This treatment increased the number of short shoots with terminal fruit buds and resulted in a doubling of crop per tree in the 2 years following treatment; similarly, secondary branch production and early cropping of Bramley's Seedling was stimulated by orchard treatment with the branching agent M\&B 25-105 (42). A similar approach with sweet cherry, but in this case using Promalin applied as a paint formulation to 1year-old shoots, increased lateral shoot production in several cultivars (36). Spur production was also increased and yields improved by up to $45 \%$ (from 29 to $42 \mathrm{~kg} /$ tree).

Treatment of young orchard trees with branching agents therefore offers an approach to improving early cropping. This method would seem to be most suited for use on cultivars exhibiting strong apical dominance, which limits the production of lateral shoots and spurs. Among apple cultivars, it seems likely that benefits from these treatments would be seen most clearly with tip-bearers and spurt y p e s.

\section{GENETIC MANIPULATION OF TREE STRUCTURE}

In the past, the emphasis in many fruit breeding programs has been on improvement of such characteristics as fruit quality, yield, hardiness, and disease resistance. In more recent years, with greater cultural emphasis being placed on containment of tree growth and reduction of pruning costs, greater consideration than before is being given to the genetic manipulation of tree structure.

\section{Mutation breeding}

In a 1936 list of nearly 800 bud mutations in temperate fruits, Shamel and Pomeroy (47) recorded no sports with altered tree habit. The first recorded spur sport of any kind, the Okanoma sport of 'Delicious' apple, had been selected in the 1920s, but it received little commercial attention (26). Apart from two 'Delicious' sports discovered in the 1930s, it was not until the 1950s that further spur sports were found. Since then, many such sports have been identified, especially in apple, and several have been adopted widely in North America. Spur-types or compact types (the terms are often used interchangeably) tend to have all or most of the following characteristics: fewer, shorter, more erect lateral shoots than regular types, and short, stout internodes, more spurs, and reduced tree size (5). Their use has given some measure of tree size control; this feature, together with other favorable attributes, including improved fruit quality characteristics, has led to their adoption by growers.

The success of spur-type apples in North America has contributed to the establishment of several tree fruit mutation breeding programs, for which a major objective is the induction of compact tree form, especially in cultivars or species not already endowed with suitable natural mutants. Among such programs, principally using radiation as the mutagen, are those established at Summerland, B. C., in 1957 (30); at Wageningen, the Netherlands, in 1965 (52); at Long Ashton, England, in 1967 (11) and at Rome in 1963 (18).

Compact mutants can be recognized by eye often in the second vegetative generation after irradiation. Early selection for compact nursery tree habit has been found to be reasonably efficient for detecting compact spur-type mutants, though more extensive trials are necessary to select against unstable chimeras and defects in flower fertility and fruit quality.

Lapins $(29,31)$ named the sweet cherries 'Lambert Compact' in 1964 and 'Compact Stella' in 1973. Recently, Fideghelli et al. (21) have described promising compact clones of the sweet cherries 'Bigarreau Burlat' and 'Durone Nero II'; Campbell and Sparks (12) describe compact mutants of the vigorous triploid apple 'Bramley's Seedling'. Field trials with these compact 'Bramley' clones indicate that, although yield per tree may be less than obtained with the normal form, yield per unit of crown volume is superior for some of the compact types, suggesting that they may be used for moreefficient production systems.

Mutation breeding promised to be a useful technique for inducing compact habit where there exists no other source of the character or where compact habit is required in an otherwise acceptable cultivar. In fruit crops other than cherry and apple, mutation breeding has been of only limited success in inducing changes in tree structure. We know of no induced habit mutants of plum, pear, peach, or apricot close to release for commercial use.

Up to the present, radiation treatment has been the method most widely used in fruit mutation breeding (33) but, in the future, emphasis is likely to change to in vitro chemical mutagenesis and the exploitation of somaclonal variation, particularly where methods for 
in vitro selection are developed. For example, Lane et al. (28) have suggested that tolerance of high levels of cytokinin may form the basis for in vitro selection of compact growth mutants.

\section{Conventional breeding}

Tree structure has been a minor consideration in many fruit breeding programs, especially in the first half of this century, although it has not been unusual for there to have been selection against extreme tree forms known or thought to be undesirable. However, early tree fruit breeders often published extensive details of seedling characteristics from numerous crosses, including data on tree habit. Tydeman (49), Matthews (35), and Crane and Lawrence (14) commented on inheritance of tree habit in apple, cherry, and plum, respectively. The occurrence of dwarf, seedlings is noted in most of these papers and more detailed accounts of dwarf types and likely genetic explanations of their segregation ratios in cherry and apple are given by Matthews (34) and Alston (2).

More recently, although characters such as fruit quality have remained important selection criteria, fruit breeders have paid more attention to improved tree structure.

Alston (3) has used 'Glou Morceau' pear as a donor of spreading habit with the aim of combining this with the semi-dwarf habit of, for example, 'Beurré Papa Lafosse', to produce trees suitable for intensive planting systems. Other workers $(8,45)$ also mention the desirability of compact or spreading habit in pear and have made crosses accordingly.

The old pear cultivar Nain Vert has a dwarf habit with short internodes, a characteristic governed by a dominant gene $\mathrm{N}$, for which 'Nain Vert' is heterozygous (15). Alston (4) and Rivalta et al. (45) are using this cultivar in crosses to produce dwarf compact pears.

More than 60 years ago, Connors (13) noted that the best tree habit for peach is an open spreading form, whereas the upright type tends to produce too much. growth at the top and is difficult to prune;. he also recorded the inheritance of tree habit for several crosses. However, little has been recorded on this topic subse-

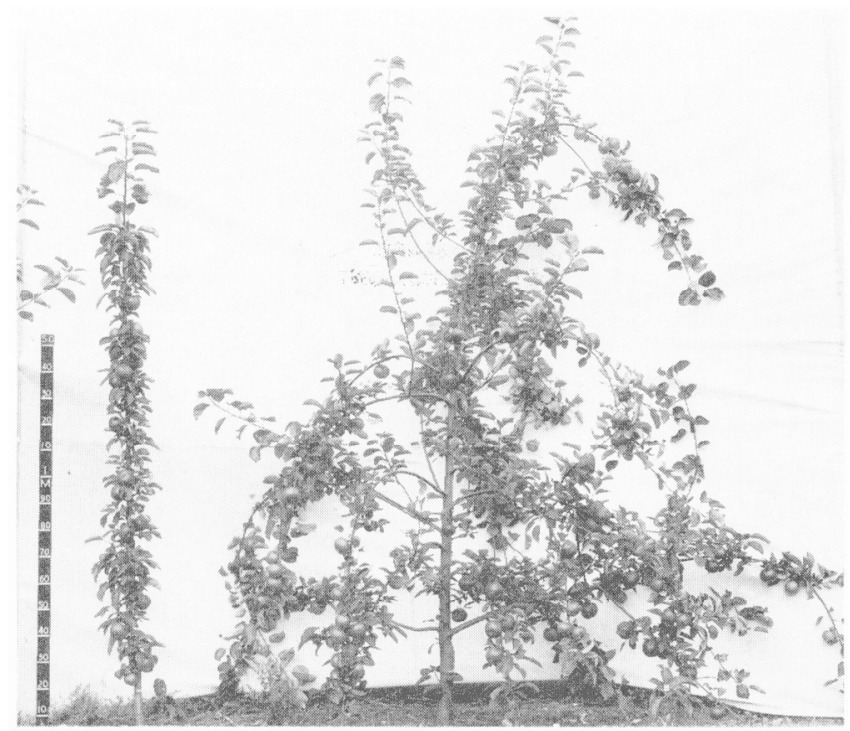

Fig. 3. 'Wijcik' sport (left) and normal 'McIntosh' (right) on MM.106. Unpruned trees in the 4 th year after planting.

quently, and modern peach cultivars are generally of an intermediate type (25).

The 'Chinese Dwarf', or 'Swatow' peach, is homozygous for a recessive gene $d w$, for brachytic dwarf habit (27). From this is derived 'Bonanza', the first dwarf peach cultivar to have been bred; it was introduced in 1962 (10). Anderson also has bred brachytic dwarf peaches, the fruit quality of which approaches that of conventional cultivars. Hansche et al. (24) investigated the cropping performance of one of Anderson's brachytic dwarfs that reaches a height of $\approx 1.8 \mathrm{~m}$ at maturity. Planted at up to 7500 trees/ha, these greatly outyielded standard peaches at conventional spacings over the first 7 years of-orchard life, eliminated the need for ladder work

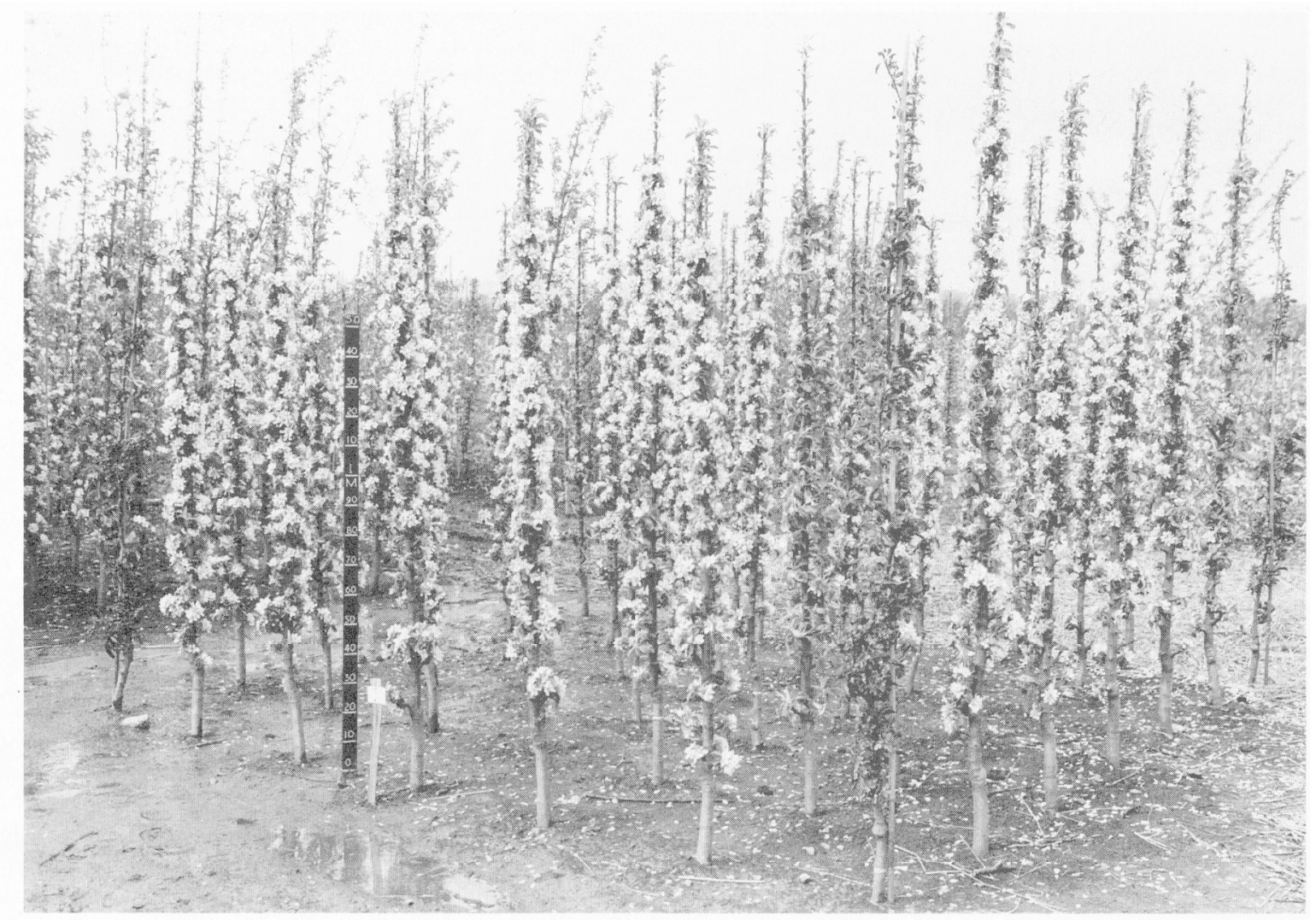

Fig. 4. Columnar apple trees in the 4 th year after planting at a spacing of $60 \times 60 \mathrm{~cm}$. 
and reduced the amount of pruning necessary. Fideghelli et al. (22) describe selections from a breeding program based on use of the recessive duplicate genes $b u_{t}, b u_{2}(27)$ to produce semi-dwarf peaches that are taller than the brachytic dwarfs.

In apple, several workers have used spur sports in crossing programs $(5,9,16,17,39,54)$, and there are various accounts of segregation for spur habit or short internodes in other progenies (32, $38,39,55)$. Among the most effective donors of such habits are 'Alkmene' (38) and 'McIntosh Wijcik' (32).

'McIntosh Wijcik' is heterozygous for a dominant gene, Co, imparting a compact growth form with short internodes and very few lateral branches (32) (Fig. 3). With minimal pruning, these trees can be maintained as a single column. At East Malling, Tobutt (48) has combined this columnar habit with other characters to produce selections likely to be useful as garden trees, as pollinizers in conventional orchards, and for very-high-density plantings (Fig. 4). Although many of the columnar seedlings tend to overset and become biennial, it has been possible to select for regular bearing. One of these regular types (SA163-17) planted in a replicated trial in 1980 on MM.106 rootstock at a spacing of $2.5 \times 0.6 \mathrm{~m}$ yielded $6 \mathrm{~kg}$ of fruit per tree in 1985 and an accumulated yield of $16.6 \mathrm{~kg}$ up to and including 1985. The relative absence of branches and the well-exposed fruit on these trees suggests that a system based on columnar trees may lend itself more readily to mechanized harvesting of dessert fruit than other growing systems in existence. Four columnar types recently named ('Maypole', 'Telamon', 'Trajan', and 'Tuscan') have been selected for garden culture.

\section{CONCLUSION}

The speed with which the fruit tree fills its allotted space determines, to a large extent, the build-up of orchard production and the age at which maximum productivity is achieved. Although the importance of planting a well-branched tree is generally recognized, particularly where high-density plantings are the norm, many cultivars are deficient in this respect. Chemical stimulation of branching can bring obvious benefits. Although rapid canopy development during the orchard establishment phase is desirable, tree size containment becomes important once the tree fills the available space. Potent growth-regulating chemicals, such as paclobutrazol, are becoming available for use on many crops, but it is inadvisable to base production systems largely on chemical growth regulation 'methods.

Steps are being taken by fruit breeders to include good tree structure as a selection criterion to improve cropping efficiency; the longterm solution to tree size containment lies with the development of compact types more suited to the requirements of modern produc-

\section{Literature Cited}

1. Abbas, M.F. 1978. Association between branching in maiden apple trees and levels of endogenous auxins. Acta Hort. 80:59-62.

2. Alston, F.H. 1976. Dwarfing and lethal genes in apple progenies. Euphytica 25:505-514.

3. Alston, F.H. 1982. Pear breeding objectives at East Mailing, p. 200206. In: T. Van Der Zwet and N.F. Childers (eds.). The pear, cultivars to marketing. Horticultural Publications, Gainesville, Fla.

4. Alston, F.H. 1982. Pear breeding, progress and prospects. Proc. of 21st Intl. Hort. Conga., Hamburg, F.R.G. 1:127-137.

5. Arasu, N.T. 1968. Spur-type sports in apples. Rpt. E. Mailing Res. Sta. 1967. p. 113-119.

6. Baldini, E., S. Sansavini, and A. Zocca. 1973. Induction of feathers by growth regulators on maiden trees of apple and pear. J. Hort. Sci. 48:327-337.

7. Barlow, H.W.B. and C. R. Hancock. 1962. The influence of the leaf upon the development of its axillary meristem. Rpt. E. Mailing Res. Sta. 1961. p. 71-76.

8. Bell, R. L., T. Van Der Zwet, and R.C. Blake. 1982. The pear breeding program of the United States Department of Agriculture, p. 157170. In: T. Van Der Zwet and N.F. Childers (eds.). The pear, cultivars to marketing. Horticultural Publications, Gainesville, Fla.

9. Blazek, J. 1983. Inheritance and genetic variation of spurred growth habit in apples. Acta Hort. 140:55-62.

10. Brooks, R.M. and H.P. Olmo. 1972. Register of new fruit and nut varieties. 2nd ed. Univ. of California Press, Berkeley.

11. Campbell, A.I. and C.N.D. Lacey. 1973. Mutation induction in fruit tree cultivars at Long Ashton. Proc. of Eucarpia Fruit Section Symp. V. Top Fruit Breeding, Canterbury, U.K. p. 40-46.

12. Campbell, A.I. and T.R. Sparks. 1986. Compact mutants: production, selection and performance in Bramley's Seedling apple. Acts Hort. 180:11-18.

13. Connors, C.H. 1923. Peach breeding. A summary of results. Proc. Amer. Soc. Hort. Sci. 19:108-115.

14. Crane, M.B. and W.J.C. Lawrence. 1938. The genetics of garden plants. 2nd ed. Macmillan, London.

15. Decourtye, L. 1967. Etude de quelques caractères a contrôle génétique simple chez le pommier (Malus sp.) et le poirier (Pyrus communis). Ann. Amélior. Plantes 17:243-266.

16. Decourtye, L. 1973. Caractéristiques comparées des descendances entre type standard et type spur de Golden Delicious et Starking Delicious. Proc. of Eucarpia Fruit Section Symp. V. Top Fruit Breeding, Canterbury, U.K. p. 47-54

17. Decourtye, L. and B. Lantin. 1969. Contribution à la connaissance des mutants spurs de pommier; hérédité du caractère. Ann. Amélior. Plantes 19:227-238.

18. Donini, B. 1975. Induction and isolation of somantic mutations invegetatively propagated plants. Improvement of vegetatively propagated plants through induced mutations, Tokai, 1974. Intl. Atomic Energy Agency, Vienna. p. 35-51.

19. Edgerton, L.J. 1979. Applications of Promalin on Red Delicious and other varieties. Proc N.Y. State Hort. Soc. 124:35-38.

20. Elfving, D.C. 1985. Comparison of cytokinin and apical-dominanceinhibiting growth regulators for lateral-branch induction in nursery and orchard trees. J. Hort. Sci. 60:447-454.

21. Fideghelli, C., A. Albertini, and P. Mannino. 1983. Advanced sweet cherry dwarf selections obtained by ionizing radiations. Acta Hort. 140:95-101.

22. Fideghelli, C., R. Quarta, G. Della Strada, and M. T. Dettori. 1983. Tree and fruit characters of several genetic semi-dwarf peach selections. Acta Hort. 140:119-124.

23. Forshey, C.G. 1982. Branching responses of young apple trees to applications of 6-benzylamino purine and gibberellin $\mathrm{GA}_{4+7}$. J. Amer. Soc. Hort. Sci. 107:538-541.

24. Hansche, P. E., C.O. Hesse, and J. Beutel. 1979. Dwarf tree potential: 'Just peachy'. Amer. Fruit Grower 99(8):12, 13, 17.

25. Hesse, C.O. 1975. Peaches, p. 285-335. In: J. Janick and J.N. Moore (eds.). Advances in fruit breeding. Purdue Univ. Press, West Lafayette, Ind.

26. Kilpatrick, D.T. 1964. New semi-dwarf "spur-type" Granny Smith. J. Agr. S. Austral. 68:57-61.

27. Lammerts, W.E. 1945. The breeding of ornamental edible peaches formild climates: 1. Inheritance of tree and flower characters. Amer. J. Bet. 32:53-61.

28. Lane, W. D., N.E. Looney, and F. Mage. 1982. A selective tissue culture medium for growth of compact (dwarf mutants of apple. Theor. Applied Genet. 61:219-223.

29. Lapins, K.O. 1965. The Lambert compact cherry. Fruit Var. Hort. Dig. 19:23.

30. Lapins, K.O. 1973. Induced mutations in fruit trees. Induced mutations in vegetatively propagated plants. Intl. Atomic Energy Agency, Vienna. p. 1-19.

31. Lapins, K.O. 1974. Compact Stella sweet cherry. Can. J. Plant Sci. 54:849-850.

32. Lapins, K.O. 1974. Spur type growth habit in 60 apple progenies. J. Amer. Soc. Hort. Sci. 99:568-572.

33. Lapins, K.O. 1983. Mutation breeding, p. 74-99. In: J.N. Moore and J. Janick (eds.). Methods in fruit breeding. Purdue Univ. Press, West Lafayette, Ind.

34. Matthews, P. 1971. The genetics and exploitation of dwarf seedlings in the sweet cherry. Proc. Angers Fruit Breed. Symp. 1970. p.319338 .

35. Matthews, P. 1973. Some recent advances in sweet cherry genetics and breeding. Proc. Eucarpia Fruit Section Symp. V. Top fruit breeding, Canterbury, U.K. p. 84-107.

36. Miller, P. 1983. The use of Promalin for manipulation of growth and cropping of young sweet cherry trees. J. Hort. Sci.58:497-503.

37, Miller, S.S. and B.J. Eldridge. 1986. Use of 6-benzylamino purine and Promalin for improved canopy development in selected apple cultivars. Scientia Hort. 28:355-368.

38. Murawski, H. 1969. Beitrage zur Züchtungsforschung beim Apfel: XIV. Beobachtungen über die Vererbung der Internodienlänge von Apfelsorten. Arch. für Gartenb. 17:3-13.

39. Oberle, G.D. 1965. The occurrence of spur type trees in seedling apple populations. Fruit Var. Hort. Dig. 19:43-46. 
40. Preston, A.P. 1968. Pruning and rootstock as factors in the production of primary branches on apple trees. J. Hort. Sci. 43:17-22.

41. Quirdan, J.D. 1978. Chemical induction of lateral branches (feathers). Acts Hort. 65:129-138.

42. Quinlan, J.D. 1981. New chemical approaches to the control of fruit tree form and size. Acts Hort. 120:95-106.

43. Quinlan, J.D. and A.P. Preston. 1973. Chemical induction of branching in nursery trees. Acts Hort. 34: 123-127,.

44. Quinlan, J.D. and A.P. Preston. 1978. The use of branching agents to replace hand pruning of young trees of Bramley's Seedling apple.. J. Hort. Sci. 53:39-43.

45. Rivalta, L., R. Quarta, G.L. Bagnara, and D. Cobianchi. 1986. Miglioramento genetico del pero presso 1'ISF di Roma. Rivista Frutti. Ortoflor 48(34):34-36.

46. Sachs, T. and K.V. Thimann. 1967. The role of auxins and cytokinins in the release of buds from dominance. Nature (London) 201:939940.

47. Shamel, A.D. and C.S. Pomeroy. 1936. Bud mutations in horticultural crops. J., Hered. 27:487-494.

48. Tobrrtt, K.R. 1985. Breeding columnar apples at East Mailing. Acts Hort. 159:63-68.
49. Tydeman, H.M. 1944. A preliminary account of experiments in breeding early and midseason dessert apples. Rpt. E. Mailing Res. Sta 1943. p. 34-42.

50. Van Oosten, H.J. 1978. Effects of initial tree quality on yield. Acts Hort. 65:123-127.

51. Van Oosten, H.J. 1981. Effects of propyl-3-t-brrtylphenoxyacetate (M\&B 25-105) on the branching of maiden apple and pear trees. Meded. Facult. Landbouw. Rijksuniv. Gent. 46:247-251.

52. Visser, T. 1973. Methods and results of mutation breeding in deciduous fruits, with special reference to the induction of compact and fruit mutations in apple. Induced mutations in vegetatively propagated plants. Intl. Atomic Energy Agency, Vienna. p. 21-33.

53. Wertheim, S.J. 1978. Manual and chemical induction of sideshoot formation in apple trees in the nursery. Scientia Hort. 9:337-345.

54. Zagaga, S. W. and M. Faust. 1983. Population analysis of vigor and growth pattern of apple seedlings with short internode parentage. J. Amer. Soc. Hort. Sci. 108:939-944.

55. Zhang, G. M., G.M. Wang, Q.Y. Zhang, W.Q. Zhang, and X.Z. Tang: 1985. Pre-selection of seedlings for spur type apples. Acta Hort. 140:63-71.

\title{
Structural Manipulation for Improved Performance in Woody Plants
}

\author{
Filiberto Loreti \\ Dipartimento di Coltivazione e Difesa delle Specie Legnose, Sezione di Coltivazioni Arboree, \\ Universitá di Pisa, Italy \\ Piero L. Pisani \\ Dipartimento di Ortoflorofrutticoltura, Universitá di Firenze, Italy
}

Physical manipulation to modify tree shape and canopy size has undergone considerable evolution since the end of the last century. In the 19th century, fruit trees were trained primarily to various geometric shapes that were influenced by esthetic considerations (Fig. 1). Scientific and socioeconomic factors have been responsible for major changes in fruit tree training in the 20th century.

Our knowledge of tree physiology has contributed greatly to understanding plant responses to pruning and training, resulting in more rational and effective training methods $(9,67)$. The shortage and costs of specialized labor have greatly influenced the evolution of pruning and training practices in horticulture. These problems have affected, to a degree, fruit production, forestry, and landscape horticulture practices. Economic factors, however, have had the greatest influence on fruit crops. Profound changes in cultural practices and particularly pruning and training techniques have resulted in improved yields, fruit quality, and reduced production costs.

Few tree crop species are cultivated without any pruning and/or training. Variations in framework and small crown size are achieved through genetic manipulation, pruning, and other cultural techniques, such as rootstock, increased tree density, and the application of growth regulators. Specific pruning techniques and training methods to position tree framework and branches in space are discussed in this paper.

\section{Physiological aspects of pruning}

Correct manipulation of tree shape requires an understanding of the natural growth habit of a species and sometimes even the cultivar (43). Growth control often depends on the interaction between environmental and genetic factors. Environmental factors include photoperiod, light intensity, temperature, moisture supply, and soil fertility. Genetic factors influence vigor and photo-morphogenic and gravimorphic reactions,

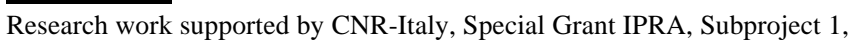
paper no. 1160.
The factors of greatest importance are the shoot/root interactions; these determine canopy size and apical dominance and its control, which, in turn, influence tree shape. The physiological basis for apical dominance and control is not fully understood, but is thought to involve a complex hormonal balance involving nutrient and gravitational influences.

An effort to relate the concepts of hormonal action and nutritional factors to apical dominance has led to the concept of mobilization, or directed translocation, as a control of lateral-bud growth. In this context, major roles are attributed to auxin transport, nutrient availability, and cytokinin level in relation to apical dominance $(1,18$, $42,72-74,78,79)$. Some authors $(19,40,44)$ consider that apical dominance and control are reciprocally related in that a plant that has strong apical dominance of lateral buds on current season's shoots has weak apical control of those buds and the shoots that develop from them the following year. Conversely, plants that have weak apical dominance of currently formed buds have strong control over the growth of lateral shoots.

Species that are characterized by strong apical dominance and weak control, such as apple, tend to assume a decurrent habit, while those with weak apical dominance and strong apical control, such as Liquidambar styraciflua L., develop an excurrent crown (Fig. 2) $(19,40,44)$. Even plants of one species do not always fit into one specific growth habit category, but often range between the two extremes. Factors affecting the expression of apical dominance and control include tree vigor, nutrient supply, crop density, and light (44).

The physiological principles of apical dominance and control have been used to obtain more uniformly branched central leaders in apple and pear cultivars. They have limited feathering (branching) ability due to strong apical dominance. Branching in these cultivars was achieved by maintaining an intact central leader in early spring, then by removing its terminal section when the last four to six shoots that were formed were 0.10 to $0.15 \mathrm{~m}$ long (Fig. 3). This practice encourages lateral bud break and shoot development in the lowermiddle region of the central leader. 